Horstmann, should not be construed as evidence that the barrier strategy is mistaken, since for several diseases the progress of transmission in these conditions is known to be quite different from that among the civilian population.

The severer critics of the present campaign believe that the Division of Biologies Standards of the National Institutes of Health, which is responsible for recommending licences for the vaccine, should have allowed more research data to accumulate before giving the programme its blessing. As it happens the attenuated virus strain on which two of the three vaccines are based was developed by two scientists in the Division of Biologics Standards, Drs H. M. Meyer and Dr P. D. Parkman. In deciding to recommend licences for the rubella vaccines the director of the CAP D division, Dr Roderick Murray, took advice from all people concerned, not excluding Drs Meyer and Parkman. But to avoid any conflict of interest Dr Murray specifically requested that no member of the Biologics Standards Division should also have a voting position on the board responsible for developing the rubella vaccines, the Vaccine Development Committee of the National Institute of Allergy and Infectious Diseases. Dr Meyer was one of the non-voting liaison members of this committee but, with his exception, no member of the Division of Biologies Standards sat on this or either of the two other committees involved, the Surgeon General's Advisory Committee on Immunization Practices and the Immunization Committee of the American Academy of Pediatrics. The latter two committees issued a joint statement at the time the rubella vaccines were licensed recommending their routine use on children.

A more moderate view of the vaccination programme is taken by the Nobel laureate Dr John Enders of the Boston Children's Hospital. In a judiciously balanced editorial article in the New England Journal of Medicine he said that the "accumulating doubts" about the long term effectiveness of the programme "should not for the present be allowed to interfere with its continuation. But in the meantime they may usefully encourage a reconsideration of other, more direct procedures, such as the vaccination of susceptible parturient women or of adolescent girls".

Though it is far too early to assess how the vaccination is working, those involved with the programmehave the impression that in areas where there has been heavy vaccination there is less rubella around than usual. Even should the campaign not succeed, there are many who will say it was worth the gamble.

\section{AIR POLLUTION Academy to Take on Detroit Oil Men} by our Washington Correspondent

THE National Academy of Sciences is a rarity among learned societies in that it is required by charter to tender practical advice, when requested by government, on the issues of the day. Unlike the British Royal Society, for example, whose only purpose in life is self-perpetuation, the National Academy dares to put the talents of its members to practical use, though with the ever present risk of offending powerful interest groups or agencies of government. The academy now seems likely to be charged with a task as awesome politically as any that it has yet faced, that of monitoring progress in meeting Senator Muskie's clean air bill which states, among other things, that all cars manufactured after January 1, 1975, will emit 90 per cent less pollutants than present models. The academy may thus be brought into conflict with the automobile manufacturers, if it finds them dragging their feet, and maybe with the producers of gasoline as well, or with the Congress should it find the legislated standards technologically impossible to meet.

The standards demanded by the Senate for 1975 model cars have not yet reached the statute book but have every chance of doing so now that they have been agreed to at a meeting this month between Senate and House conferees. What the House and Senate have yet to agree upon is the precise role to be played by the National Academy in seeing that the legislation is fulfilled. It appears that the academy will not be asked, as at one time seemed likely, to say at this moment whether the 1975 deadline for reduced emissions is technologically fcasible. At the meeting between Senate and House conferees on October 8, it was agreed that the academy should prepare reports at six-monthly intervals, the first being due next July, on the progress made by the manufacturers towards meeting the deadline. But the academy may also be required to comment in its six-monthly reports on the progress made in light of what is technologically feasible at the time-in other words, on whether the carmakers are trying hard enough. In assessing what is technologically feasible the academy will not be asked to consider price as a factor.

One point at which the academy's advice will clearly be crucial is in deciding the option, allowed for in the bill, of postponing the deadline by one year should the manufacturers be able to prove to a federal court that it is too harsh. The precise description of the Academy's role will be decided when the conferees from the Senate and House meet again next month. The Academy is said to have refused government requests for advice only half a dozen times in its existence and is unlikely to pass up this one, however great the temptation.

\section{ANTARCTICA \\ MSF declared Sole Heir}

\section{by our Washington Correspondent}

Tre National Science Foundation will become the most puissant power in Antarctica, following President Nixon's decision last week that the foundation should be the sole channel for funding United States work in the continent. The budget of the NSF will be increased by $\$ 25$ million when the transfer of programmes from the Department of Defense and the Coast Guard is complete. But the changeover will not necessarily mean more money for Antarctic research, since the programmes to be transferred are concerned almost wholly with providing logistical support to existing research efforts.

This year the foundation is spending $\$ 7.5$ million on all forms of Antarctic research, which at the height of the season, during the austral summer, brings some 200 scientists and technicians to the four year-round bases the United States maintains at Byrd, McMurdo, Palmer and the Amundsen-Scott South Pole station. The eleven major projects being supported this year include a balloon study of cosmic rays under $\mathrm{J}$. Barcus at the University of Denver, continued exploration by 
Ohio State University of the rich fossil fields excavated last year, and a study of the plasmapause under $\mathrm{J}$. Katsufrakis at Stanford University.

The US Army Cold Region Research and Engineering Laboratory, which has the distinction of having drilled cores down to bedrock through both the Antarctic and Greenland icecaps, is not venturing forth on the ice this summer. The intriguing record of climatic history that is stored in these cores-the ratio of oxygen isotopes in ice samples at various depths gives a measure of the temperature prevailing when the snow was formed-is unfortunately very expensive to extract. The core drilled at Byrd station in the summer of 1968-69 cost some $\$ 250,000$ and the determination of the ${ }^{18} \mathrm{O} /{ }^{16} \mathrm{O}$ ratio costs $\$ 50$ a sample, although this part of the research, conducted under $W$. Dansgaard at the University of Copenhagen, is supported by the Danish government.

The ice at the bottom of the Byrd station core is about 70,000 years old, whereas that in the Camp Century core from Greenland is nearer 100,000 years. There are plans to drill another core through the Antarctic ice cap, probably as part of an international glaciological programme in which the Soviet Union, Britain and France would participate. A second core would hopefully extend the climatic record further back into the Pleistocene as well as providing a fuller comparison with the thousand century temperature chart extracted from Greenland.

\section{MALNUTRITION}

\section{New York Children lack Vitumin A}

\section{by our New York Correspondent}

A WIDESPREAD deficiency of vitamin A among children in New York City, particularly those from lowerincome homes, was reported last week by Dr Robert Newman, director of the National Nutritional Survey of New York City, at a meeting of the New York Academy of Sciences. Dr Newman noted that there is still no agreement as to what constitutes malnutrition, each scientist defining it according to his own frame of reference. But he hoped that the New York survey, along with those being conducted in ten other states, would enable present definitions and techniques to be re-evaluated.

The New York study figures released last week are based only on laboratory analyses, so that correlation of dietary deficiencies with specific symptoms or illnesses must wait until the clinical examination results have beentabulated. Deficiency of vitamin A is known to contribute to a loss of vision in poor light, but it is not known how great the deficiency must be before sight is affected. There is also great disagreement over what constitutes the "minimal daily requirements" of nutrients. For example, in Britain $20 \mathrm{mg}$ is considered an adequate daily amount of vitamin $C$, while in the United States the common figure is $70 \mathrm{mg}$. The National Survey originally defined the requirement as $60 \mathrm{mg}$ but dropped this level in the course of the survey to $30 \mathrm{mg}$. The distinction must also be made between nutritional levels and "good eating habits". Dr Newman pointed out that the reason why so few people were found with vitamin $\mathrm{C}$ deficiencies might well be because it is added to many sodas and soft drinks. "These drinks are still frowned upon and not considered a desirable source for this nutrient," he said.
Forty-six per cent of children under seven years old in lower income families were found to have vitamin A deficiency, compared with 18 per cent of children of that age in upper income families. Between the ages of seven and twelve the figures were 27 per cent for the lower-income and 25 per cent for the upper. Ten per cent of the low-income children between seven and twelve were deficient in vitamin $B$, riboflavin, com. pared with six per cent of the upper-income children of that age group. For purposes of the study, the dividing line between lower and upper income families was placed at an annual income of $\$ 4,156$ for a family of four.

\section{COMMUNICATIONS}

\section{Beware the Polluted Spectrum}

IT is admirable that the National Academy of Engineering should be aware of the electromagnetic spectrum as a natural resource that is in as much danger of pollution as any river, but the latest report by the panel on spectrum value is a crashing disappointment*. The lengthy report now published could almost stand as a deliberate example of how words can be a pollutant. That itself does not auger well for the spectrum. The aim of course is to devise a sensible way of deciding how to parcel out the finite band of the electromagnetic spectrum that can be used for such activities as communications, radar, aircraft control and so on. Part of the reason for the continuing importance of this topic is that parts of the spectrum at shorter wavelengths than used to be impracticable to use are now being opened up through the development of new equipment and the pressure on the conventional wavebands. What the panel has been trying to do without much luck is to think up some social and economic criteria that can be applied to the judgments that have to be made about the purposes to which unused parts of the spectrum are to be applied. To begin with the report expresses surprise that up to now things have gone as well as they have, in the United States at least, with a system of spectral management which the report criticizes. For example, the panel finds that the Federal Communications Commission is slow at coming to decisions, usually hears evidence only from those directly involved in a contest over a particular band, and has inadequate technical advice. What the panel would like to see is more representation for the general public above that which the officials of the FCC themselves provide, and a better backing staff to provide the technical background and speed up the negotiations. The reason these deficiencies have not made themselves felt more strongly earlier, the report says, is that technical advances have tended to cover up where mistakes have been made. The panel makes no secret that what it would really like is a formula to express the social and economic value of a given application of part of the spectrum as an index. Reluctantly the panel concludes that no satisfactory formula is likely to be devised. All that the panel can suggest then is to strengthen the present methods of allocation. What this boils down to is that the people who have to make the decisions about the use of the spectrum should be backed by better advisory teams, and it is a shame that this lukewarm recommendation is all that the panel can find to say.

* The Application of Social and Economic Values to Spectrum Management, available from the Committee on Telecommunications, National Academy of Engineering, Washington DC. 